\title{
Strategies for production, characterization and application of protein-based biostimulants in agriculture: A review
}

\author{
Jesús M. Moreno-Hernández ${ }^{1 *}$, Israel Benítez-García ${ }^{2}$, Miguel A. Mazorra-Manzano ${ }^{3}$, \\ Juan C. Ramírez-Suárez ${ }^{3}$ and Esteban Sánchez ${ }^{4}$
}

\begin{abstract}
${ }^{1}$ Instituto Nacional de Investigaciones Forestales, Agrícolas y Pecuarias (INIFAP), Carretera Culiacán-Eldorado km 17,5, Sinaloa, México. ${ }^{*}$ Corresponding author (moreno.jesus@inifap.gob.mx).

${ }^{2}$ Universidad Politécnica de Sinaloa (UPSIN), Carretera a Higueras km 3, Sinaloa, México.

${ }^{3}$ Centro de Investigación en Alimentación y Desarrollo (CIAD, A.C.), Gustavo Enrique Astiazaran Rosas 46, Sonora, México

${ }^{4}$ Centro de Investigación en Alimentación y Desarrollo (CIAD, A.C.), Vencedores del Desierto, Chihuahua, México.
\end{abstract}

Received: 28 August 2019; Accepted: 27 December 2019; doi:10.4067/S0718-58392020000200274

\begin{abstract}
Nowadays agriculture is facing constantly challenges to produce more and better food for a growing population under a changing climate scenery. To afford this demand, agricultural practices must innovate in new methods for crop production, nutrition management, and plant health. In addition, the development of new compounds or biological agents able to improve plant yield (regulating plant physiology, metabolism, crop performance), and agro-product quality, are also necessary. In the last decade, agents with these characteristics have been proposed for a sustainable agriculture. These agents, defined as biostimulants, have showed to improve plant nutrition, quality, yield and abiotic tolerance in different agricultural crops. In particular, the use of protein hydrolysates as biostimulants offers promising results to reduce the use of agrochemicals and improve productivity parameters in a variety of cultivars, in agree with the modern agricultural production challenges. The present review is focused in the use of protein hydrolysates as plant biostimulants, describing typical and potential agro industrial by-products as sources substrates for protein-based biostimulants formulation, and commercial or experimental proteolytic enzymes used for hydrolysate production. Moreover, critical aspects during protein biostimulants manufacture, functional profiling and its applications are discussed. Finally, recent advances for the evaluation of protein hydrolysates on plant physiology and metabolism under experimental and commercial scale are also documented. Concluding in the necessity to conduct structural studies, in order to identify and produce bioactive peptides with agricultural applications.
\end{abstract}

Key words: Bioactives, biostimulants, hydrolysates, peptides, proteases.

\section{INTRODUCTION}

Agriculture is an important sector that influences several aspects of economy, technology as well as social development of countries. The aim of food sovereignty requires of policies to guarantee supply and access to high quality food for all population. In the last decade, this concept acquired high relevance remaining as one of the primary goals in the agri-food sector. According to Food and Agriculture Organization (FAO) of the United Nations, the global population in the next $40 \mathrm{yr}$ will increase to 9.2 billion people, which will require enough quality food. Therefore, a strategic vision involves efforts to increase production of basic agricultural products considering water availability, emerging pests, loss of soil productivity, and other factors associated with climate change (FAO, 2017). To affront these challenges, innovative agricultural practices under organic or biological concepts for a sustainable crop production are required, optimizing the natural resources utilization and reducing environmental impacts. In this way, some biological compounds have 
been developed to improve crops development and productivity. These substances called plant biostimulants, stimulate physiological processes in plants, and are able to enhance crop yield, quality and induce tolerance or recovery from abiotic stress (du Jardin, 2015). In particular, protein-based biostimulants have attracted the interest of the scientific community and agricultural industry. Its use in combination with good agronomic practices, have beneficial effects in plant metabolism through different mechanisms such as the increase in $\mathrm{N}$ dynamics, carbohydrates biosynthesis, photosynthesis rate and root development (du Jardin, 2015). Evidences indicate that some endogenous peptides can mediate biochemical responses against pathogens and regulate many other cellular events in plants (Lindsey et al., 2002). The biological properties of these hormonal peptides suggest that application of polypeptides in protein hydrolysate could induce similar physiological and metabolic responses in plants.

Protein modification by enzymatic process represents an attractive and powerful biotechnological tool for the production of protein hydrolysates $(\mathrm{PH})$. Protein hydrolysates are nutritive compounds with functional and/or bioactive properties and multiple applications in areas such as medicine, nutrition, food, and agriculture. The identification and characterization of the biostimulants properties PH represent an attractive research area that needs to be explored in more detail. Therefore, this review provides information about technological tools available and potentially applicable to agricultural practices, emphasizing in the use of $\mathrm{PH}$ as biostimulants. Characteristics of proteins sources and proteolytic enzymes (traditional and new sources) for its production and methods for PH characterization are described. In addition, some physiological and metabolic processes occurring in plants treated with PH under experimental and commercial trail conditions, are also reviewed.

\section{Peptides as plant biostimulants}

The interest of agricultural science in the use of PH as plant biostimulants represent a new emerging research areas. The scientific evidences support that some peptides expressed by plants have hormonal activities and modulate key biochemical processes, according to biotic and abiotic stimulus (Lindsey et al., 2002). Examples include the hormonal polypeptide family called systemin, synthetized as a response to herbivorous insects in tobacco leaves, the bifunctional peptide NOD40, which is related with root nodulation in alfalfa, soybean and rice (Takayama and Sakagami, 2002). The biological properties of these hormonal peptides open the possibility that exogenous application of polypeptides by the use of PH could induce similar physiological and metabolic responses in plants.

As fundament, the use of PH in horticulture started with the assumption that plant can readily uptake di/tri peptides and oligopeptides both radicular and foliar manner. First approximations in this area were performed in Europe in the 70's, with the application of commercial protein hydrolysate Siapton (bovine epithelium hydrolysate) in maize, with evident improvement of maize growth (Mladenova, 1978). The experimentation with Siapton in other agronomic crops like tomato, showed new biostimulant effects (fruit size, chemical composition and nutrient quality) in addition to growth rate (Parrado et al., 2008). These evidences encouraged the development of a new generation of PH, employing different low value protein sources or by-products, and extensive literature have been published on this regard (Colla et al., 2015). In contrast, limited reviews are focused in the technology for PH production (e.g. protein substrate selection, proteases screening, hydrolysis conditions, peptide characterization) and the next sections of this review are conducted in this sense.

\section{Protein sources for hydrolysate production}

Effluents or by-products from agriculture and food industry requires innovative processes and new technologies to reduce cost, optimize natural resources and minimize its environmental impacts. Some estimations indicate annual discards of around 9 thousand tons of dairy proteins (Rajarajan et al., 2016), 3 million tons of protein-rich seafood wastes (Ferraro et al., 2010), and 8 million tons of proteins from livestock by-products (Martínez-Álvarez et al., 2015) with huge negative implications to the environment. All these proteins sources are good substrates for protein-derived biostimulants production.

Amino acids composition is a key factor in protein source selection due its importance as protein building blocks, and anabolic precursors. In addition, the primary amino acid sequence has a huge impact in substrate solubility, hydrolysis degree, amino acids balance and bioavailability for plants. For example, skins, bones, heads, tails and carcasses from seafood processing are enriched in collagen. This protein has a high proportion of proline, a key amino acid in plant physiology due their role as phytohormone precursor, as well as pollen fertility and water balance regulator (Hausler et al., 2014), which makes them very attractive for the formulation of protein-based biostimulants. Other hand, some modified amino acids like hydroxylysine and hydroxyproline are also present in collagen, these are unusual in plants and may be 
limited in its metabolization. Furthermore, collagen structure imparts partial insolubility and may restrict its susceptibility to hydrolysis for certain proteases, implicating additional pretreatments during the hydrolysate production (Muralidharan et al., 2013). Similar limitation in solubility is presented by keratins from chicken feathers; high energy consumption processes are required from its processing. Thus, enzymatic or fermentative processes (protease-producer strains) are more suitable to obtain hydrolysates from this source. In other hand, dairy proteins (caseins, whey proteins) or livestock by-products (hemoglobin, plasm proteins) possess a diversity of hydrophobic and polar amino acids in their primary structures, and numerous of possible cleavage sites for proteases (Lafarga et al., 2016), producing a mix of peptides and olipeptides with different chemical properties, and potential bioactive functions.

Advance in bioinformatics makes possible the virtual screening of food and non-food proteins. Online tools can be used to explore protein physicochemical properties in order to identify potential substrates for hydrolysate production. For instance, UniProt database has been developed for high-throughput protein sequences analysis (Uniprot Consortium, 2015). This database displays different protein annotations sets for a target substrate to facilitate de discovery of new properties, like functional peptide release. For example, rapid sequence analysis of bovine hemoglobin beta-chain (UniProt P02070-1) can be developed to identify in-silico cleavage site by different proteases. Figure 1 shows output data sets from

Figure 1. Screening of hemoglobin cleavage sites by different proteases.

A Sequence:

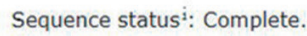

Positions of cleavage sites

2939115143

1945506777789297127

128

1314364041447084102117121129144

12131427303136404144475462677074767780849790 919596102104105109113117121125129140142144145

2939115143

5621254289100120

1212132627304043444647697076798084868789909495 101102103104108109112113116120125128129139140

1212132627303435404344464769707679808486878990 9495101102103104108109112113116120125128129139140

521254289100120

137891112161826293031323940434952535860656669 7376869496101103104107108109110111112113116123124 126131132133135136138139140

71618293958606465758194103115119131143

Sequence annotation section of hemoglobin beta subunit by UniProt, UniProt P02070, https://www.uniprot.org/uniprot/P02070 (A) and ExPASy PeptideCutter tool for virtual cleavage sites screening (B). 
bovine hemoglobin sequence analysis by combining UniProt and ExPASy PeptideCutter tools. In this case, all possible peptide sequences can be inferred according to the position of cleavage sites for a particular protease. In the same way, the content of free $\alpha$-amino per protein molecule indirectly suggest the hydrolysis degree of the substrate, high free $\alpha$-amino correspond to high hydrolysis degree, as show most experimental studies (Spellman et al., 2003). Many proteins from by-products (collagen, gelatin, albumins) can be virtually screening through this technology. Although in the practice, this approach has been used for food and biomedical purposes (Szerszunowicz and Nalecz, 2018), information provided by these tools can be used in order to estimate amino acid balance and peptide characteristics during the selection of suitable substrates for biostimulants design.

Actually, crude preparations of proteins from animal and vegetable wastes are used for protein-based biostimulants production. Agricultural by-products are the most popular substrates for this purpose. For instance, amaranth, alfalfa hay and legume seeds are common substrates in commercial biostimulants, maybe due their availability and the presence of phytohormones, phenols and mineral elements with additional biostimulant effects in plants (Lucini et al., 2015). Case of animal PH, several hydrolysates have been produced from connective tissue, skin and plasm proteins (i.e. hemoglobin), these are successfully applied in commercial crops with positive results (Wilson et al., 2018). However, contrary effects (e.g. phytotoxic and chlorosis events) have been also reported, almost attributed to unfavorable amino acid balance, excessive free amino acids, and osmolytes content (Cerdán et al., 2009), parameters strongly related with the method of $\mathrm{PH}$ production. Today, stable and safety animal-derived hydrolysates applied to agricultural plants can be manufactured by enzymatic process and applied at commercial level (Polo et al., 2006; Marfa et al., 2009).

\section{Protein hydrolysate production and profiling}

The cleavage of peptide bonds in protein (hydrolysis) generally result in a mixture of free amino acids and peptides, which characteristics will depend of the process used and degree of hydrolysis (DH) attained. Chemical hydrolysis of proteins by acid or alkaline treatments at high temperature $\left(121-137^{\circ} \mathrm{C}\right)$, is a drastic process that result in product with high content in free amino acids, destruction of several amino acids (e.g., Lys, Trp, Ser, Thr, Cys), and conversion from L-forms to D-form of amino acids; limiting their metabolism and causing other toxic effects in plants (Cerdán et al., 2009). In contrast to chemical method, $\mathrm{PH}$ produced by enzymatic proteolysis are more advantageous because they allow better control of the final product (hydrolysis control), low energy requirement and enzymes can be used for different batches. Production of PH by enzymatic methods can be performed under controlled conditions at a desired DH and by selective peptide cleavage by using specific proteases, maximizing peptide/oligopeptides proportion and yields, as well its physicochemical characteristics like solubility, diffusion and abortion (Pecha et al., 2012). Almost all PH characteristics including its biostimulant properties are strongly influenced by the type of protease.

Proteases used for PH production include those from microorganisms, animals and plants. The type of proteolytic enzyme used depends of the conditions for optimum enzymatic activity, as well as its specificity over certain substrates. Aspartic proteases (Asp residue at the catalytic site) such as pepsin from animal origin and onopordosin from the plant Onopordum acanthium, hydrolyze proteins preferentially at the acidic range (pH 2-5) (Dunn, 2002). Cysteine proteases (Cys residue at the catalytic site) such as chymotrypsin, papain and bromelain, catalyze reactions preferably under neutral conditions (Grzonka et al., 2007). Serine proteases (Ser residue at the catalytic site) such as trypsin and cucumisin from melon are more active in the alkaline region (Antao and Malcata, 2005). Metaloproteases such as some collagenases and keratinases, contain metals as cofactors and are active in a broader $\mathrm{pH}$ (Daboor et al., 2012). Microbial proteases like Subtilisin, Thermolysin and Flavourzyme are used for treatment of effluents with high protein load, these enzymes are especially attractive for their resistance to surfactants agents in wastes, and are commercially available (Liu et al., 2014). Actually, plants proteases offer excellent properties for food and co-products bioprocessing for biofunctional peptide release (Mazorra-Manzano et al., 2018). These enzymes have been successfully employed for specific hydrolysis of myofibrillar proteins, hemoglobin and collagen (Mazorra-Manzano et al., 2015), as well as cereal grains (Faulds et al., 2009) and milk proteins (whey, caseins) (Mazorra-Manzano et al., 2018), principal protein components in livestock, seafood, agricultural, and dairy by-products. Table 1 shows some common proteases and its potential substrates as candidates for manufacture novel protein-based biostimulants. 
Table 1. Proteases and substrates candidates for protein-based biostimulant production.

\begin{tabular}{|c|c|c|c|}
\hline Enzyme & Source & Substrates & Reference \\
\hline \multicolumn{4}{|c|}{ Animal proteases } \\
\hline $\begin{array}{l}\text { Pepsin } \\
\text { (Asp) }\end{array}$ & $\begin{array}{l}\text { Purified formulate from gastric extract (stomach) of } \\
\text { fish or livestock by-products }\end{array}$ & Gelatin, hemoglobin, sarcoplasmic proteins & Khaled et al. (2011) \\
\hline $\begin{array}{l}\text { Trypsin }^{\mathrm{a}} \\
\text { (Ser) }\end{array}$ & $\begin{array}{l}\text { Purified enzyme from digestive tract from chicken } \\
\text { or bovine tissues }\end{array}$ & $\begin{array}{l}\text { Caseins, gelatin, myofibrillar proteins, hemoglobin, } \\
\text { oat proteins, sarcoplasmic proteins }\end{array}$ & Oliveira et al. (2005) \\
\hline \multicolumn{4}{|c|}{ Microbial proteases } \\
\hline $\begin{array}{l}\text { Alcalase } \\
\text { (Ser) }\end{array}$ & $\begin{array}{l}\text { Fermentation-produced protease from Bacillus spp. } \\
\text { NCIB, pure form }\end{array}$ & $\begin{array}{l}\text { Caseins, collagen, gelatin, sarcoplasmic, myofibrillar } \\
\text { proteins }\end{array}$ & Gupta et al. (2002) \\
\hline $\begin{array}{l}\text { Subtilisin } \\
\text { (Ser) }\end{array}$ & $\begin{array}{l}\text { Fermentation-produced enzyme from Bacillus } \\
\text { subtilis JB1, pure form }\end{array}$ & Albumin, caseins, gelatin & $\begin{array}{l}\text { Sung et al. (2010) } \\
\text { de Castro and Sato }\end{array}$ \\
\hline $\begin{array}{l}\text { Flavourzyme } \\
\text { (C-peptidase) }\end{array}$ & $\begin{array}{l}\text { Complex semipurified enzymes produced by } \\
\text { fermentation of Aspergillus oryzae LBA01 strain }\end{array}$ & $\begin{array}{l}\text { Globulins, hemoglobin, ovalbumin, soy proteins } \\
\text { Keratins }\end{array}$ & (2014) \\
\hline $\begin{array}{l}\text { Keratinase } \\
\text { (Ser) }\end{array}$ & $\begin{array}{l}\text { Produced by microbial fermentation Paenibacillus } \\
\text { woosongensis TKB2 }\end{array}$ & & Paul et al. (2013) \\
\hline \multicolumn{4}{|l|}{ Plant proteases } \\
\hline $\begin{array}{l}\text { Papain } \\
\text { (Cyst) }\end{array}$ & $\begin{array}{l}\text { Crude extract or purified enzyme from Carica } \\
\text { papaya latex }\end{array}$ & $\begin{array}{l}\text { Casein, gelatin, myofibrillar proteins, serum proteins, } \\
\text { soybean proteins }\end{array}$ & $\begin{array}{l}\text { Fernández-Lucas et al. } \\
\text { (2017) }\end{array}$ \\
\hline $\begin{array}{l}\text { Bromelain } \\
\text { (Cys) }\end{array}$ & Purified enzyme from Ananas comosus stem & $\begin{array}{l}\text { Albumin, caseins, collagen, gelatin, hemoglobin, } \\
\text { myofibrillar proteins }\end{array}$ & Arshad et al. (2014) \\
\hline $\begin{array}{l}\text { Cucumisin } \\
\text { (Ser) }\end{array}$ & Purified enzyme from Cucumis melo fruit sarcocarp & $\begin{array}{l}\text { Albumin, caseins, fish proteins, myoglobin, } \\
\text { ovoalbumin, whey proteins }\end{array}$ & $\begin{array}{l}\text { Antao and Malcata } \\
(2005)\end{array}$ \\
\hline $\begin{array}{l}\text { Citrus proteases } \\
\text { (Asp, Cys, Ser) }\end{array}$ & $\begin{array}{l}\text { Raw enzymatic extract from Citrus aurantium } \\
\text { flowers }\end{array}$ & $\begin{array}{l}\text { Albumin, caseins, fish myofibrillar proteins, gelatin, } \\
\text { hemoglobin }\end{array}$ & $\begin{array}{l}\text { Mazorra-Manzano et } \\
\text { al. (2015) }\end{array}$ \\
\hline $\begin{array}{l}\text { Pinguinains } \\
\text { (Cys) }\end{array}$ & $\begin{array}{l}\text { Crude extract or purified enzymes from Bromelia } \\
\text { pinguin fruits mesocarp }\end{array}$ & Albumin, caseins, hemoglobin & $\begin{array}{l}\text { Moreno-Hernández et } \\
\text { al. (2017) }\end{array}$ \\
\hline
\end{tabular}

Aspartic (Asp), serine (Ser) and cysteine (Cys) proteases; C-peptidase: carboxypeptidase.

${ }^{a}$ Refer to Zhao et al. (2011) for enzyme details.

${ }^{\mathrm{b}}$ Available from different suppliers, consult Gupta et al. (2002).

${ }^{\mathrm{c}}$ Commercialized in different physical forms, see Feijoo-Siota and Villa (2011).

Protease specificity determines the position at which the enzyme catalyze peptide bond hydrolysis, e.g. trypsin release preferentially in N-terminal Arg and Lys, pepsin cleave in hydrophobic and aromatic residues, and subtilisin inside in peptides bonds between large uncharged residues. The use of these proteases as single catalyzer or in combination, determines DH, free amino acids/peptides ratio, and sequences of peptides in PH (Tavano, 2013). For example, Flavourzyme, Alcalase, Novo Pro-D and coralase produce hydrolysates from potatoes wastes with $22 \%, 8 \%, 3 \%$ and $2 \%$ of DH, respectively, but combining $2 \%$ Alcalase $+5 \%$ Flavourzyme is increased to $44 \%$ DH (Kamnerdpetch et al., 2007). Usually, biostimulants in horticulture are characterized for a moderate DH and low free amino acids. Alfalfa and connective tissue hydrolysates possess a $29 \%$ and $18 \%$ DH, respectively (Ertani et al., 2009), carob hydrolysate have a $20 \% \mathrm{DH} / 8 \%$ free $\alpha$-aminos ratio (Parrado et al., 2007), commercial hydrolysate Siapton has $14.5 \%$ DH and $7.9 \%$ free $\alpha$-aminos (Polo et al., 2006), while Amino 16, Trainer, StresSal just report a free amino acid content in a range 7\%11\% (Tsouvaltzis et al., 2014; Lucini et al., 2015; Visconti et al., 2015). Due that hydrolysate absorption and peptide bioavailability for plant are strongly influenced by hydrolysis degree, this parameter needs to be carefully controlled during hydrolytic process during biostimulants profiling.

Physicochemical and biological properties of $\mathrm{PH}$ require of rigorous procedures, depending of the area of interest. Figure 2 shows the general diagram for the production and profiling of protein-based as biostimulants. In order to identify the peptide sequence with biostimulants activity, it is necessary to perform several protocols for their purification and characterization as well as for the evaluation of putative bioactivity. Purification protocols using ion exchange (anionic or cationic resins) and gel filtration (molecular exclusion) in low-pressure columns are commonly used, depending of ligand characteristics (Ali et al., 2010). Ultrafiltration also is a common task for fractionation of protein/peptides components in hydrolysates, and enrich some fractions in peptide content. Molecular weight (MW) and the number of amino acid residues are the most important factors in peptides bioactivity. Smaller peptides $(<7$ amino acids or with a MW 700-800 Da) are 
Figure 2. Scheme for production protein hydrolysates from by-products.

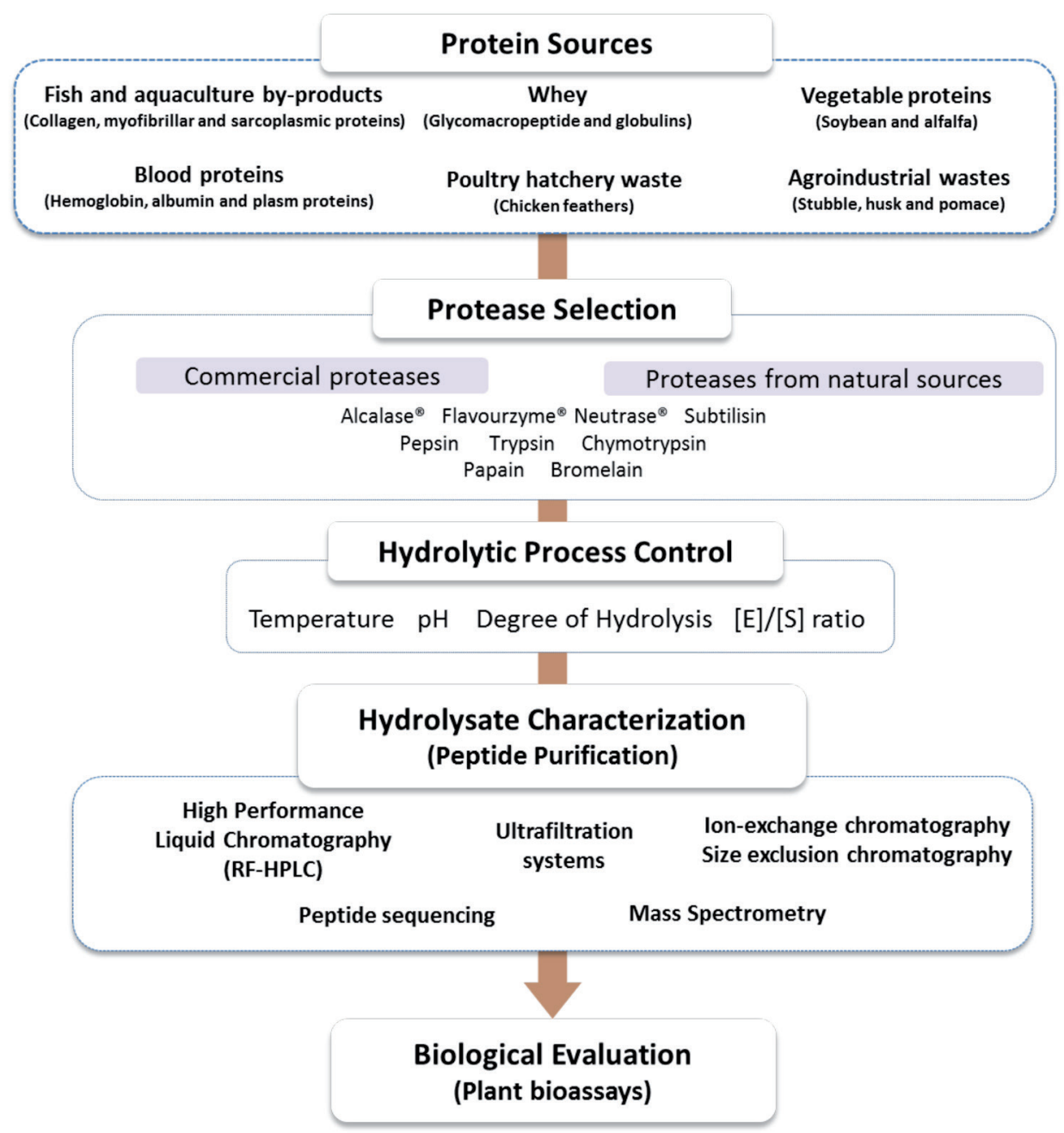

usually the most active but their short chain makes it more likely for them to be shared among several proteins, and their analysis difficult by conventional proteomic approaches. Medium peptides with a chain length (7-25 aa or 800$3000 \mathrm{Da}$ ) also show a significant bioactivity and are the most common identified in proteomic analysis (when trypsin is used) because most of them are unique for a specific protein. Large peptides are difficult to analyze, instead, and only a few bioactive peptides are known (Capriotti et al., 2015). However, analytical systems such as high-resolution liquid chromatography (HPLC) allow the purification of peptides with high resolution and quantification. Mass spectrometry detectors coupled to this system (HPLC-MS) allow peptidomic analysis of PH (Lahrichi et al., 2013). There are no studies in peptidic characterization of $\mathrm{PH}$ with biostimulant effects in plants, some reports are only focused in describing a general response to particular PH (e.g. gibberellin-like and auxin-like activity, hormonal factors and effectors in nodulation); but no specific peptide sequence has been associate to these biological activities. Hence, are necessary subsequent studies in purification and sequencing of peptides present in these $\mathrm{PH}$, studies on structure-function relationship of protein-derived plant biostimulants are also recommended.

\section{Protein hydrolysates evaluation and its effects in plants}

The evaluation of hydrolysates as plant biostimulant involves a series of considerations and progressive tests to observe key responses in plants at physiological and metabolic level (Figure 3). The response to biostimulants has also been explored in schemes of hydroponic crops, growth chambers, greenhouse, pots and field crops. Studies in model systems 
Figure 3. Factor involved in the evaluation of experimental protein-based biostimulants.

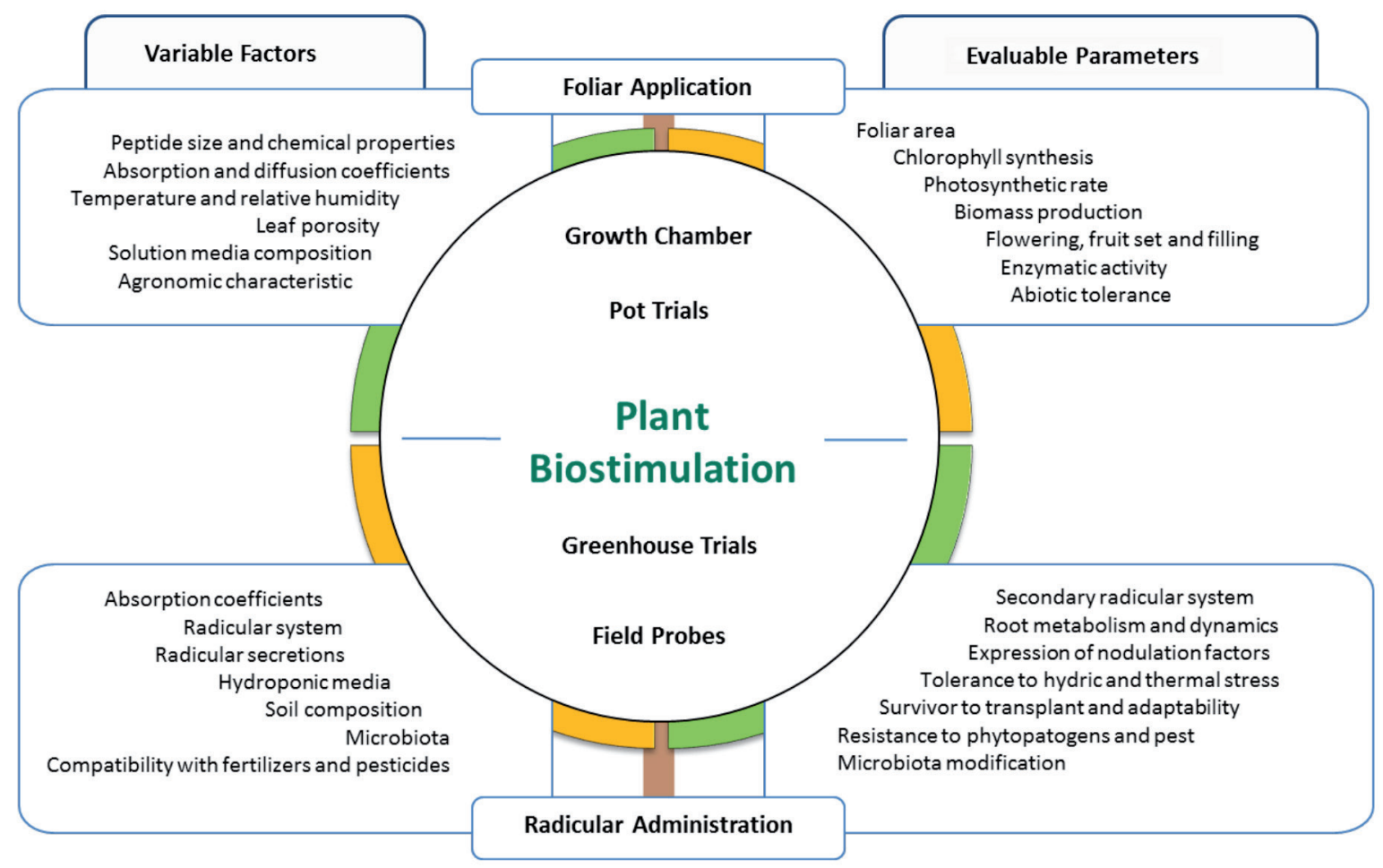

allow the evaluation of plant response more efficiently since they can manage climatic conditions of specific regions, field conditions and plant species (Pecha et al., 2012). The in-vitro plant culture allows the control of biotic and abiotic factors, light cycles, and nutrient media composition for the growth of the species tested. The effect on the development of root systems, stem growth or callus induction in plant tissue culture, allows the identification of substances that induce specific tissue growth. Generally, basal media used for plant culture incorporates organic elicitors like yeast extract and casein hydrolysate (Al-Khayri, 2011). However, PH from other protein sources have been explored for their incorporation into substrates for plant tissue culture and micro-propagation (Eguchi et al., 2000). Studies with pots under greenhouse conditions using fertigation or foliar application of $\mathrm{PH}$, are the most common strategies (Table 2). Nutrient solution composition is a key factor in fertigation assays. Hydrolysates can be incorporated into fertigation solutions, high solubility (hydrophilic peptides) is recommended to prevent insoluble aggregates or undesirable interactions with other nutrients (Schiavon et al., 2008; Ertani et al., 2009). Absorption coefficient of peptides through the root system, secretion of proteolytic enzymes by the root, soil components and microbiota also are important factors to consider for nutrient uptake. Foliar application must be considered since stomata in leaf cuticle play an important role in permeability and absorption (Tejada et al., 2018). Other important factors to consider are peptide size, environmental conditions (relative humidity, temperature, evaporation parameters) and leaf area for peptide absorption (Koukounararas et al., 2013).

As shows Table 2, commercial and experimental PH have been assayed in a variety of crops, including ornamentals, fruit trees, horticultural vegetables, and cereals. Many of these protein-based biostimulants successfully improved plant development, marketable fruit yield, quality, and nutraceutical characteristics. For instance, the commercial biostimulant Trainer applied by irrigation to tomato under greenhouse conditions, enhanced nutritional status of plants, increasing plant height, shoot biomass and fruit yield (Rouphael et al., 2017). Similar results are also reported with the foliar dosage of this biostimulant in lettuce (Luziatelli et al., 2019). These effects have been attributed to the activation of enzymes related with $\mathrm{N}$ and $\mathrm{C}$ metabolisms, to support high plant growth rates and biomass productivity (Sestili et al., 2018). In maize, Siapton application enhanced the activity of NAD-dependent glutamate reductase, nitrate reductase and malate dehydrogenase (Maini, 2006), and alfalfa hydrolysate evidenced a transcriptional upregulation of enzymes in central pathways (Schiavon et al., 2008). Most crops treated with protein-derived biostimulants show increased plant height, leaf numbers, root development, fruit set and filling (Marfa et al., 2009; Gurav and Jadhav, 2013). Furthermore, several 
Table 2. Crop responses to experimental and commercial protein hydrolysates (PH) biostimulants.

\begin{tabular}{|c|c|c|c|c|c|}
\hline Crop & Level & Product & Assay & Crop responses & Reference \\
\hline Apple & Experimental & $\begin{array}{l}\text { Alfalfa protein } \\
\text { hydrolysate }\end{array}$ & Field trial (foliar) & $\begin{array}{l}\text { Increases fruit quality and sensorial } \\
\text { characteristics (color index, sugar } \\
\text { content) } \\
\text { Improves nutraceutical value } \\
\text { (anthocyanin content) } \\
\text { Reduces post-harvest disease } \\
\text { "Jonathan spot" } \\
\text { Crop responses observed in } \\
\text { consecutive seasons }\end{array}$ & Soppelsa et al. (2018) \\
\hline Banana & Experimental & $\begin{array}{l}\text { Chicken feathers } \\
\text { hydrolysate }\end{array}$ & $\begin{array}{l}\text { Field trial (fertigation- } \\
\text { foliar) }\end{array}$ & $\begin{array}{l}\text { Increases photosynthetic rate and } \\
\text { chlorophyll content } \\
\text { Reduces time to flowering } \\
\text { Enhances fruit set, filling and yield } \\
\text { Improves antioxidant potential and } \\
\text { nutraceutical value }\end{array}$ & Gurav and Jadhav (2013) \\
\hline Chickpea & Experimental & $\begin{array}{l}\text { Chicken feathers } \\
\text { hydrolysate }\end{array}$ & $\begin{array}{l}\text { Greenhouse } \\
\text { (fertigation) }\end{array}$ & $\begin{array}{l}\text { Seed priming improves germination } \\
\text { rate and survivor to transplant } \\
\text { Promotes secondary roots } \\
\text { development and increase biomass } \\
\text { production } \\
\text { Increases 3-fold root nodulation } \\
\text { respect to untreated plants } \\
\text { PH displays phytohormone-like } \\
\text { activities }\end{array}$ & Paul et al. (2013) \\
\hline $\begin{array}{l}\text { Cucumber } \\
\text { Maize } \\
\text { Tomato }\end{array}$ & Experimental & Gelatin hydrolysate & $\begin{array}{l}\text { Greenhouse (solid } \\
\text { capsule) }\end{array}$ & $\begin{array}{l}\text { Improves seed priming and } \\
\text { germination } \\
\text { Hydrolysate enhances plantlet } \\
\text { growth } \\
\text { Increases shoot dry weight } \\
\text { Enhances } \mathrm{N} \text { metabolism mediated by } \\
\text { amino acid permeases (aap3, aap6) } \\
\text { activation }\end{array}$ & Wilson et al. (2018) \\
\hline \multirow[t]{2}{*}{ Grapevine } & Experimental & $\begin{array}{l}\text { Carob germ } \\
\text { hydrolysate }\end{array}$ & Field trial (fertigation) & $\begin{array}{l}\text { Increases phenolic and anthocyanin } \\
\text { content } \\
\text { Enhances nutraceutical value }\end{array}$ & Parrado et al. (2007) \\
\hline & Experimental & $\begin{array}{l}\text { Soybean and } \\
\text { casein hydrolysates }\end{array}$ & Cell culture media & $\begin{array}{l}\text { Induces tolerance against } \\
\text { Plasmopara viticola pathogen } \\
\text { Reduces infected leaf surface }(63 \% \text { - } \\
70 \%) \\
\text { Up-regulation of defense genes } \\
\text { encoding pathogenesis-related (PR) } \\
\text { protein } \\
\text { Stimulation of secondary metabolites } \\
\text { biosynthesis: stilbene and resveratrol }\end{array}$ & Lachhab et al. (2014) \\
\hline Kiwifruit & Experimental & Gelatin hydrolysate & Pot trial (foliar) & $\begin{array}{l}\text { Increases shoot and root biomass } \\
\text { Improves assimilation and } \\
\text { metabolism of } \mathrm{N} \\
\text { PH shows similar results to } \\
\text { traditional urea fertilization }\end{array}$ & Qurartieri et al. (2002) \\
\hline \multirow[t]{2}{*}{ Lettuce } & Experimental & Alfalfa hydrolysate & $\begin{array}{l}\text { Growth chamber } \\
\text { (fertigation) }\end{array}$ & $\begin{array}{l}\text { Increase root development and } \\
\text { nutrient acquisition } \\
\text { PH displays gibberellin-like } \\
\text { activities }\end{array}$ & Ertani et al. (2009) \\
\hline & Experimental & $\begin{array}{l}\text { Legume seeds } \\
\text { hydrolysate }\end{array}$ & $\begin{array}{l}\text { Greenhouse } \\
\text { (fertigation-foliar) }\end{array}$ & $\begin{array}{l}\text { Increases growth rate, protein and } \\
\text { chlorophyll production. Enhance } \\
\text { survival, tolerance to salinity and } \\
\text { oxidative stress }\end{array}$ & Lucini et al. (2015) \\
\hline
\end{tabular}


Continuation Table 2.

\begin{tabular}{|c|c|c|c|c|c|}
\hline Crop & Level & Product & Assay & Crop responses & Reference \\
\hline & Experimental & $\begin{array}{l}\text { Hemoglobin } \\
\text { hydrolysate }\end{array}$ & $\begin{array}{l}\text { Growth chamber } \\
\text { (fertigation) }\end{array}$ & $\begin{array}{l}\text { Induces resistance to thermal stress } \\
\text { Maintains specific growth rate and } \\
\text { increases quality and yield }\end{array}$ & Polo et al. (2006) \\
\hline & Commercial & Amino 16 & $\begin{array}{l}\text { Greenhouse } \\
\text { (fertigation-foliar) }\end{array}$ & $\begin{array}{l}\text { Increases crop uniformity and } \\
\text { antioxidant content } \\
\text { Regulates nitrate assimilation in } \\
\text { leaves } \\
\text { Enhances adaptability to thermal } \\
\text { stress }\end{array}$ & Tsouvaltzis et al. (2014) \\
\hline & Commercial & Trainer ${ }^{\circledR}$ & Greenhouse (foliar) & $\begin{array}{l}\text { Enhances plant growth, productivity, } \\
\text { fresh marketable yield } \\
\text { Modulates K uptake } \\
\text { Osmotic regulator under salt stress }\end{array}$ & Luziatelli et al. (2019) \\
\hline \multirow[t]{3}{*}{ Maize } & Experimental & $\begin{array}{l}\text { Alfalfa protein } \\
\text { hydrolysate }\end{array}$ & $\begin{array}{l}\text { Greenhouse } \\
\text { (fertigation) }\end{array}$ & $\begin{array}{l}\text { Increases foliar area, biomass } \\
\text { production and grain yield } \\
\text { Metabolic analysis reveals activation } \\
\text { of key enzymes in central pathways } \\
\text { PH induces activation of amino acid } \\
\text { biosynthesis in roots }\end{array}$ & Schiavon et al. (2008) \\
\hline & Experimental & $\begin{array}{l}\text { Connective-tissue } \\
\text { hydrolysate }\end{array}$ & $\begin{array}{l}\text { Growth chamber } \\
\text { (fertigation) }\end{array}$ & $\begin{array}{l}\text { Stimulates secondary root system } \\
\text { and plant growth } \\
\text { Increases radicular area and nutrient } \\
\text { uptake } \\
\text { Activation of glutamine synthase } \\
\text { activity in root } \\
\text { PH displays auxin-like activity }\end{array}$ & Ertani et al. (2009) \\
\hline & Experimental & $\begin{array}{l}\text { chicken feathers } \\
\text { hydrolysate }\end{array}$ & Field trial (foliar) & $\begin{array}{l}\text { Significantly increases of maize } \\
\text { nutrition status } \\
\text { Enhances grain yield and quality } \\
\text { Modulates leaf cuticle permeability }\end{array}$ & Tejada et al. (2018) \\
\hline Pepper & Experimental & Alfalfa hydrolysate & Greenhouse (foliar) & $\begin{array}{l}\text { Increases fresh weight and number } \\
\text { of fruits per plant } \\
\text { Stimulates secondary metabolites } \\
\text { in fruits } \\
\text { Improves phytochemicals content } \\
\text { and nutraceutical value }\end{array}$ & Ertani et al. (2014) \\
\hline Persimmon & Commercial & StresSal & Field trial (fertigation) & $\begin{array}{l}\text { Stimulates the biosynthesis of salt- } \\
\text { stress response proteins } \\
\text { Osmoregulation under high ionic } \\
\text { strength }\end{array}$ & Visconti et al. (2015) \\
\hline Soybean & Commercial & Terra-sorb complex & Field trial (foliar) & $\begin{array}{l}\text { Increases number of pods and seed } \\
\text { yield } \\
\text { Improves nutraceutical (phenolic, } \\
\text { flavonoid) value and oil content }\end{array}$ & Kocira (2019) \\
\hline Strawberry & Experimental & $\begin{array}{l}\text { Hemoglobin } \\
\text { hydrolysate }\end{array}$ & $\begin{array}{l}\text { Greenhouse } \\
\text { (fertigation) }\end{array}$ & $\begin{array}{l}\text { Stimulates radicular system } \\
\text { Increases biomass production and } \\
\text { yield } \\
\text { Reduces days to flowering and } \\
\text { improve fruit set and filling }\end{array}$ & Marfa et al. (2009) \\
\hline Tomato & Commercial & Trainer & Greenhouse (foliar) & $\begin{array}{l}\text { Enhances plant height, leaf number } \\
\text { and shoot biomass } \\
\text { High photosynthetic rate and } \\
\text { increase of nutritional status } \\
\text { Higher marketable fruit yield } \\
\text { Improves soluble solids content and } \\
\text { functional fruit quality }\end{array}$ & Rouphael et al. (2017) \\
\hline
\end{tabular}


Continuation Table 2.

\begin{tabular}{|c|c|c|c|c|c|}
\hline Crop & Level & Product & Assay & Crop responses & Reference \\
\hline & Commercial & Trainer & $\begin{array}{l}\text { Greenhouse } \\
\text { (fertigation) }\end{array}$ & $\begin{array}{l}\text { Activation of ammonium, nitrate } \\
\text { transporters and enzymes involved } \\
\text { in } \mathrm{N} \text { metabolism } \\
\text { Increases root and total plant dry } \\
\text { weight }\end{array}$ & Sestili et al. (2018) \\
\hline Wheat & Commercial & Terra-sorb complex & Field trial (foliar) & $\begin{array}{l}\text { Increases C fixation via Rubisco } \\
\text { activation } \\
\text { Improves photosynthetic rate and } \\
\text { sugar production }\end{array}$ & $\begin{array}{l}\text { Martínez-Esteso et al. } \\
\text { (2016) }\end{array}$ \\
\hline
\end{tabular}

studies also showed an increase in secondary metabolites. For example, foliar application of alfalfa hydrolysate in pepper increased the content of phytochemicals (chlorogenic acid, $p$-hydroxybenzoic acid, $p$-coumaric acid) and other phenols (Ertani et al., 2014). A similar hydrolysate in apple increased the anthocyanin content in fruit, improving sensorial quality and nutraceutical properties (Soppelsa et al., 2018), as well as carob tree hydrolysate in grapevine (Parrado et al., 2007).

The clear mechanism of PH biostimulants on plant remains uncertain, but a lot evidences suggest that specific amino acids and/or peptides in hydrolysates could mimic the action of naturally occurring peptide hormones in plants (also known as signaling peptides). These molecules are involved in the regulation of several growth and developmental processes, determining the shape of flowers and leaves, controlling roots length and thickness of stem or inducing secondary metabolism biosynthesis through the activation of multiple signaling pathways that involve second messengers such as $\mathrm{Ca}^{2+}$, cyclic adenosine monophosphate (CAMP), cyclic guanosine monophosphate (cGMP), cyclic ADP ribose (cADPR), guanosine triphosphate (GTPase), 1,2-diacylglycerol (DAG) or inositol 1,4,5 triphosphate (IP3) to traduce various development signal, are not linear but are interconnected by complex network and even feedback mutually to achieve the final outcome (Wang and Irving, 2011). The action mechanism by PH is probably similar to that reported for plant peptide hormones (systemin, phytosulfokinine, SCR/SPII, ENOD40, plant natriuretic peptide [PNPs], 5-locus-cysteine-rich protein [SCPs] and CLAVATA3), which possess signal sequences that are detected by putative leucine-rich repeat (LRR) type receptor like kinase (RLKs) or by pattern recognition receptor (PRRPs) and receptor like protein (RLP), since these receptors can presumably act as multi-domain proteins able to bind to different ligands like peptides or small molecules (Kondo et al., 2006; Zhou et al., 2019). All these receptors play key roles in transducing signals to downstream signaling pathways for cellular responses (plant resistance, growth and development). The general mechanism begins when a signal peptide is recognized by an appropriate receptor, and then a signal is transmitted via mitogen-activated protein kinase (MAPK) pathways to intracellular signaling networks, through a series of phosphorylation events, establishing eventually a cellular response. MAPK cascades represent a key convergent module among intracellular pathways. A MAPK cascade contains three sequentially activated kinases; a MAPK kinase kinase (MAPKKK), a MAPK kinase (MAPKK) and MAPK (Yamada et al., 2016), which can further phosphorylate diverse protein substrates for regulating plant growth, development and immunity (Figure 4A). In this manner, MAPK cascades can control a wide range of defense responses, including the expression of immune genes, induction of ethylene, biosynthesis of camalexin and production of reactive oxygen species (ROS), responses that increase the accumulation of signaling molecules and hormones like gibberellins, inhibit abscisic acid (ABA) biosynthesis during germination, decrease apical growth by the accumulation of indole-3-acetic acid (IAA), or down-regulate the expression of MADS transcription factor (transcription factor involved in the regulation of ABA biosynthesis and protection against abiotic stress) (Yu et al., 2017). On the other hand, peptide binds to phytosulfokine receptor (PSK) receptor, increase cytosolic $\mathrm{Ca}^{2+}$ levels leading an auxin dependent immune response by the enhancement of binding activity between calmodulin (CAM) and the auxin biosynthetic YUCs protein (flavin containing monooxygenase) for auxin biosynthesis from indole-3-pyruvate (IPA) to IAA (Figure 4B) (Zhang et al., 2018). Also the interaction of a peptide and its receptor leads the activation of jasmonic acid (JA) biosynthesis by octadecanoid pathway; JA induces defense gene expression for synthesis of defensive proteinase inhibitor (Figure 4C) (Sun et al., 2011). Although, the activation of these metabolic pathways by protein hydrolysates is still under study, the responses observed at primary and secondary metabolic levels in crops exposed to these compounds, suggest a similar signaling mechanisms. 
Figure 4. General schema proposed for the action mechanism of peptide-based biostimulants.

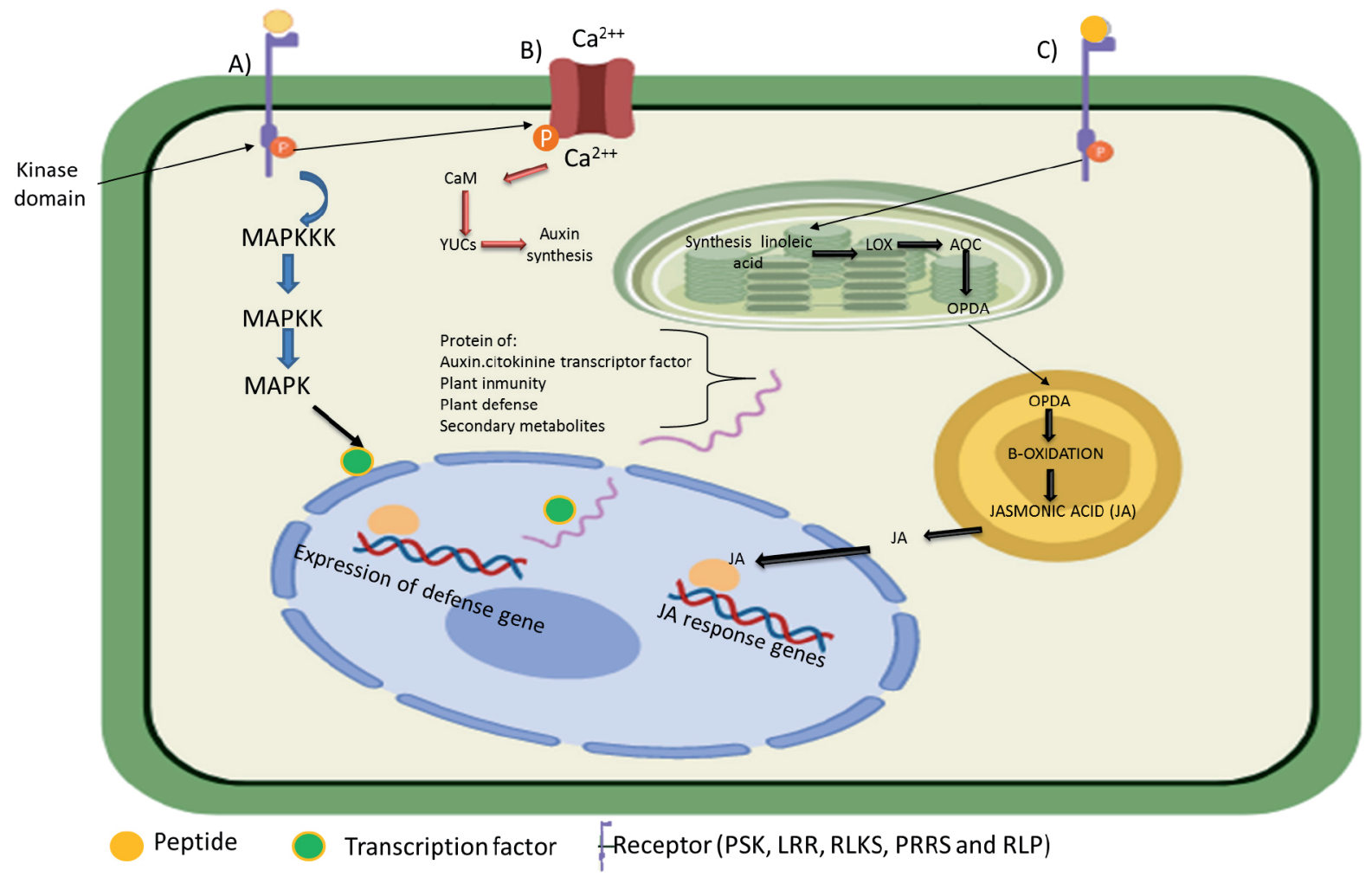

A) Binding of peptide-receptor and MAPK cascade; B) Biosynthesis of auxin mediate by activation of $\mathrm{Ca}^{2+}$ channel; and C) Effect of peptide on jasmonic acid (JA) biosynthesis.

AOC: Allene oxide cyclase; CaM; calmodulin; LOX: lipoxygenase; LRR: leucine-rich repeat; MAPK: mitogen-activated protein kinase; MAPKK: MAPK kinase; MAPKKK: MAPK kinase kinase; OPDA: 12-oxo-phytodienoic acid; PRRS: pattern recognition receptor; PSK: phytosulfokine receptor; RLKS: receptor like kinase; RLP: receptor like protein; YUCs: YUCCA family of flavin monooxygenase-like enzymes.

Protein-based biostimulants have also showed mediate plant adaptation to different conditions. For example, chicken feathers and gelatin hydrolysates used for seed priming, increased germination rate and survival in chickpea and maize, respectively (Paul et al., 2013; Wilson et al., 2018). These hydrolysates also induced root development (auxin-like activity) in both cultivars, improving plantlet adaptation to soils with nutrient deficit. By other hand, some biostimulants are formulated to maintain plant productivity under stressful conditions. StresSal and Trainer have been employed as osmo-regulator in persimmon and lettuce, to avoid negative impact of saline stress in susceptible cultivars (Visconti et al., 2015; Luziatelli et al., 2019). Ertani et al. (2009) observed a variation in the activity of phenylalanine ammonia lyase (key enzymes in phenyl-propanoid pathway) with the consequent accumulation of flavonoid in maize cultivated under salinity stress. The increased activity of phenylalanine ammonia lyase by this treatment suggests that amino acids or peptides in PH mediate adaptive responses by up-regulation genes related with salinity stress. Some studies suggest that accumulation of glycine betaine and proline are associated with increased stress tolerance, and exogenous applications of protein-based compounds in maize, barley, soybean, alfalfa and rice have been highly correlated (Ahmad et al., 2013). By other hand, experimental hydrolysate from porcine blood hemoglobin and commercial Amino 16, displayed protective effect in lettuce cultivated under extreme climate conditions, hydrolysates showed thermo-protective functionality toward warm and chilling conditions, respectively (Polo et al., 2006; Tsouvaltzis et al., 2014). Protective effects in some protein-based stimulants have been attributed to proline and proline-precursors compounds (glutamate and ornithine) in hydrolysates, due their osmolyte and chemical chaperone roles under various stressful sceneries during plant development (Szabados and Savouré, 2010). Other evidences suggest that amino-derived compounds mediate plant adaptive responses to contaminated soil with heavy metals, due its properties like metal ion chelating, antioxidant, scavenging free radical, and osmo-regulator functions, improving plant performance in toxic soils for plants (Sharma and Dietz, 2006). 
Recently a high-throughput phenotyping platform and metabolomic technologies have been proposed to elucidate the complete response of plants to protein-based biostimulants (Martínez-Esteso et al., 2016; Rouphael et al., 2018). For instance, crops like lettuce (Lucini et al., 2015), wheat (Pichereaux et al., 2019), and rice (Naito et al., 2017) have been analyzed by one of these approaches. Recently, Paul et al. (2019) applied these approaches to profile the effects of vegetable $\mathrm{PH}$ in tomato. In this trial, tomato cultured in a controlled chamber showed reprograming metabolic rates involved in ethylene, polyamines, and ROS-mediated signaling pathways. This non-invasive technology has resulted in a powerful tool for metabolic pathway measurement of plant growth, morphology, color and photosynthetic performance in response to biostimulants. In the near future, this technology can be used to modulate plant behavior under different stress conditions, becoming a powerful tool for the design of protein-based biostimulants with specialized biological characteristics, and elucidate complex mechanism of commercial or experimental PH in a whole plant according to plantenvironment interactions.

\section{CONCLUSIONS}

In the coming years, agriculture will face the challenge of producing more and better food for a growing population under adversities of a changing climate. To face this challenge, it is necessary to break the limitations of traditional agriculture and include new technologies to agricultural practices with friendly environment concept. Protein hydrolysates (PH) as biostimulants offer a new alternative to increase crop nutrition, its use may reduce the application of chemical fertilizers in many crops, especially but not limited to horticulture. Most commercial protein-based biostimulants are formulated from vegetable protein sources but actually animal proteins are also used for the production of these biostimulants with additional functionality (e.g. enhancing plant abiotic tolerance). Based on protein source availability, food by-products represent an attractive option for $\mathrm{PH}$ biostimulants production, considering that food-processing industries discard large volumes effluents with high protein load. Revalorization of these compounds by their conversion into bioactive substances with agricultural purpose not only will reduce environmental impacts caused by these discharges but also can benefit the agricultural practices by the production of plant biostimulants. During biostimulants formulations, protein byproducts can be selected according to peptides encrypted in its primary sequence, and its putative bioactivity. Proteases used for hydrolysate production can be screening bases on desirable hydrolysis degree, free amino acid balance, and physicochemical properties of the final biostimulants. To accelerate the production and screening of novel biostimulants, it is necessary to increase the scientific knowledge about bioactive peptide for plants. Studies about peptides structurefunction in correlation with metabolomic and physiological effects are necessary. To achieve this, different biotechnological tools need to be coupled in a rational design to high-throughput hydrolysates production, in order to elucidate bioactive peptide functionality and accelerate the development of effective protein-based biostimulants products according to producer's necessities.

\section{REFERENCES}

Ahmad, R., Lim, C.J., and Kwon, S.Y. 2013. Glycine betaine: a versatile compound with great potential for gene pyramiding to improve crop plant performance against environmental stresses. Plant Biotechnology Reports 7:49-57. doi:10.1007/s11816-012-0266-8.

Ali, I., Aboul-Enein, H.Y., Singh, P., Singh, R., and Sharma, B. 2010. Separation of biological proteins by liquid chromatography. Saudi Pharmaceutical Journal 18:59-73. doi:10.1016/j.jsps.2010.02.001.

Al-Khayri, JM. 2011. Influence of yeast extract and casein hydrolysate on callus multiplication and somatic embryogenesis of date palm (Phoenix dactylifera L.) Scientia Horticulturae 130:531-535. doi:10.1016/j.scienta.2011.07.024.

Antao, C.M, and Malcata, F.X. 2005. Plant serine proteases: biochemical, physiological and molecular features. Plant Physiology and Biochemistry 43:637-650. doi:10.1016/j.plaphy.2005.05.001.

Arshad, Z.I., Amid, A., Yusof, F., Jaswir, I., Ahmad, K., and Loke, S.P. 2014. Bromelain: an overview of industrial application and purification strategies. Applied Microbiology and Biotechnology 98:7283-7297. doi:10.1007/s00253-014-5889-y.

Capriotti, A.L., Cavaliere, C., Foglia, P., Piovesana, S., Samperi, R., Zenezini, R., et al. 2015. Development of an analytical strategy for the identification of potential bioactive peptides generated by in vitro tryptic digestion of fish muscle proteins. Analytical and Bioanalytical Chemistry 407:845-854. doi:10.1007/s00216-014-8094-z. 
Cerdán, M., Sánchez-Sánchez, A., Oliver, M., Juárez, M., and Sánchez-Andreu, J.J. 2009. Effect of foliar and root applications of amino acids on iron uptake by tomato plants. Acta Horticulturae 830:481-488. doi:10.17660/ActaHortic.2009.830.68.

Colla, G., Nardi, S., Cardarelli, M., Ertani, A., Lucini, L., Canaguier, R., et al. 2015. Protein hydrolysates as biostimulants in horticulture. Scientia Horticulturae 196:28-38. doi:10.1016/j.scienta.2015.08.037.

Daboor, S.M., Budge, S.M., Ghaly, A.E., Brooks, M.S., and Dave, D. 2012. Isolation and activation of collagenase from fish processing waste. Advances in Bioscience and Biotechnology 3:191-203. doi:10.4236/abb.2012.33028.

de Castro, J.S., and Sato, H.H. 2014. Protease from Aspergillus oryzae: Biochemical characterization and application as a potential biocatalyst for production of protein hydrolysates with antioxidant activities. Journal of Food Processing 2014:111. doi:10.1155/2014/372352.

du Jardin, P. 2015. Plant biostimulants: Definition, concept, main categories and regulation. Scientia Horticulturae 196:3-14. doi:10.1016/j.scienta.2015.09.021.

Dunn, B.M. 2002. Structure and mechanism of the pepsin like family of aspartic peptidases. Chemical Reviews 34:4431-4458. doi:10.1021/cr010167q.

Eguchi, Y., Milazzo, M.C., Ueno, K., and Shetty, K. 2000. Partial improvement of vitrification and acclimation of oregano (Origanum vulgare L.) tissue cultures by fish protein hydrolysates. Journal of Herbs, Spices and Medicinal Plants 6:29-38. doi:10.1300/J044v06n04_04.

Ertani, A., Cavani, L., Pizzeghello, D., Brandellero, E., Altissimo, A., Ciavatta, C., et al. 2009. Biostimulant activity of two protein hydrolyzates in the growth and nitrogen metabolism of maize seedlings. Journal of Plant Nutrition and Soil Science 172:237-244. doi:10.1002/jpln.200800174.

Ertani, A., Pizzeghello, D., Francioso, O., Sambo, P., Sanchez-Cortes, S., and Nardi, S. 2014. Capsicum chinensis L. growth and nutraceutical properties are enhanced by biostimulants in a long-term period: chemical and metabolomic approaches. Frontiers in Plant Science 5:375. doi:10.3389/fpls.2014.00375.

FAO. 2017. The future of food and agriculture. Trends and challenges. Food and Agricultural Organization of United Nations (FAO), Rome, Italy. Available at http://www.fao.org/3/a-i6583e.pdf (accessed December 2018).

Faulds, C.B., Collins, S., Robertson, J.A., Treimo, J., Eijsink, G.H., Hinz, W.A., et al. 2009. Protease-induced solubilisation of carbohydrates from brewers spent grain. Journal of Cereal Science 50:332-336. doi:10.1016/j.jcs.2009.01.004.

Feijoo-Siota, L., and Villa, T.G. 2011. Native and biotechnologically engineered plant proteases with industrial applications. Food and Bioprocess Technology 4:1066-1088. doi:10.1007/s11947-010-0431-4.

Fernández-Lucas, J., Castañeda, D., and Hormigo, D. 2017. New trends for a classical enzyme: Papain, a biotechnological success story in the food industry. Trends in Food Science and Technology 68:91-101. doi:10.1016/j.tifs.2017.08.017.

Ferraro, V., Cruz, I.B., Jorge, R.F., Malcata, F.X., Pintado, M.E., and Castro, M.L. 2010. Valorisation of natural extracts from marine source focused on marine by-products: A review. Food Research International 43:2221-2233. doi:10.1016/j.foodres.2010.07.034.

Grzonka, Z., Kasprzykowski, F., and Wiczk, W. 2007. Cysteine proteases. p. 181-195. In Polaina, J., and MacCabe, A.P. (eds.) Industrial enzymes. Springer, Berlin, Germany.

Gupta, R., Beg, Q., and Lorenz, P. 2002. Bacterial alkaline proteases: molecular approaches and industrial applications. Applied Microbiology and Biotechnology 59:15-32. doi:10.1007/s00253-002-0975-y.

Gurav, R., and Jadhav, J. 2013. A novel source of biofertilizer from feather biomass for banana cultivation. Environmental Science and Pollution Research 20:4532-4539. doi:10.1007/s11356-012-1405-z.

Hausler, R.E., Ludewig, F., and Krueger, S. 2014. Amino acids - a life between metabolism and signaling. Plant Science 229:225-237. doi:10.1016/j.plantsci.2014.09.011.

Kamnerdpetch, C., Weiss, M., Kasper, C., and Scheper, T. 2007. An improvement of potato pulp protein hydrolyzation process by the combination of protease enzyme systems. Enzyme and Microbial Technology 40:508-514. doi:10.1016/j. enzmictec.2006.05.006.

Khaled, H.B., Ghorbel-Bellaaj, O., Hmidet, N., Jellouli, K., Ali, N.H., Ghorbel, S., et al. 2011. A novel aspartic protease from the viscera of sardinelle (Sardinella aurita): Purification and characterisation. Food Chemistry 128:847-853. doi:10.1016/j.foodchem.2011.03.104.

Kocira, S. 2019. Effect of amino acid biostimulant on the yield and nutraceutical potential of soybean. Chilean Journal of Agricultural Research 79:17-25. doi:10.4067/S0718-58392019000100017.

Kondo, T., Sawa, S., Kinoshita, A., Mizuno, S., Kakimoto, T., Fukuda, H., et al. 2006. A plant peptide encoded by CLV3 identified by in situ MALDI-TOF MS analysis. Science 313:845-848. doi:10.1126/science.1128439.

Koukounararas, A., Tsouvaltzis, P., and Siomos, A.S. 2013. Effect of root and foliar application of amino acids on the growth and yield of greenhouse tomato in different fertilization level. Journal of Food Agriculture and Environment 11:644-648. doi:10.1234/4.2013.4387.

Lachhab, N., Sanzani, S.M., Adrian, M., Chiltz, A., Balacey, S., Boselli, M., et al. 2014. Soybean and casein hydrolysates induce grapevine immune responses and resistance against Plasmopara viticola. Frontiers in Plant Science 5:716. doi:10.3389/fpls.2014.00716. 
Lafarga, T., Rai, D.K., O'Connor, P., and Hayes, M. 2016. Generation of bioactive hydrolysates and peptides from bovine hemoglobin with in vitro renin, angiotensin-I-converting enzyme and dipeptidyl peptidase-IV inhibitory activities. Journal of Food Biochemistry 40:673-685. doi:10.1111/jfbc.12259.

Lahrichi, S.L., Affolter, M., Zolezzi, I.S., and Panchaud, A. 2013. Food peptidomics: Large scale analysis of small bioactive peptides-A pilot study. Journal of Proteomics 88:83-91. doi:10.1016/j.jprot.2013.02.018.

Lindsey, K., Casson, S., and Chilley, P. 2002. Peptides: new signalling molecules in plants. Trends in Plant Science 7:78-83. doi:10.1016/S1360-1385(01)02194-X.

Liu, Y.,Li, X., Chen,Z., Yu, J., Wang,F., and Wang,J. 2014. Characterization of structural and functional properties of fish protein hydrolysates from surimi processing by-products. Food Chemistry 151:459-465. doi:10.1016/j.foodchem.2013.11.089.

Lucini, L., Rouphael, Y., Cardarelli, M., Canaguier, R., Kumar, P., and Colla, G. 2015. The effect of a plant-derived biostimulant on metabolic profiling and crop performance of lettuce grown under saline conditions. Scientia Horticulturae 182:124-133. doi:10.1016/j.scienta.2014.11.022.

Luziatelli, F., Ficca, A.G., Colla, G., Svecová, E.B., and Ruzzi, M. 2019. Foliar application of vegetal-derived bioactive compounds stimulates the growth of beneficial bacteria and enhances microbiome biodiversity in lettuce. Frontiers in Plant Science 10:60 1-16. doi:10.3389/fpls.2019.00060.

Maini, P. 2006. The experience of the first biostimulant, based on aminoacids and peptides: A short retrospective review on the laboratory researches and the practical results. Fertilitas Agrorum 1:29-43.

Marfa, O., Cáceres, R., Polo, J., and Ródenas, J. 2009. Animal protein hydrolysate as a biostimulant for transplanted strawberry plants subjected to cold stress. Acta Horticulturae 842(842):315-318. doi:10.17660/ActaHortic.2009.842.57.

Martínez-Álvarez, O., Chamorro, S., and Brenes, A. 2015. Protein hydrolysates from animal processing by-products as a source of bioactive molecules with interest in animal feeding: A review. Food Research International 73:204-212. doi:10.1016/j.foodres.2015.04.005.

Martínez-Esteso, M.J., Vilella-Antón, M.T., Sellés-Marchart, S., Martínez-Márquez, A., Botta-Catala, A., et al. 2016. A DIGE proteomic analysis of wheat flag leaf treated with TERRA-SORB ${ }^{\circledR}$ foliar, a free amino acid high content biostimulant. Journal of Integrated Omics 6:9-17. doi:10.5584/jiomics.v6i1.188.

Mazorra-Manzano, M.A., Moreno-Hernández, J., Torres-Llanez, M., Ramírez-Suarez, J., González-Córdova, A., and VallejoCórdoba, B. 2015. Evaluation of Citrus aurantium flower as a new source of proteases for fish hydrolysate production. Research \& Reviews: Journal of Food and Dairy Technology 3(4):1-4.

Mazorra-Manzano, M.A., Ramírez-Suarez, J.C., Yada, R.Y. 2018. Plant proteases for bioactive peptides release: A review. Critical Reviews in Food Science and Nutrition 58:2147-2163. doi:10.1080/10408398.2017.1308312.

Mladenova, Y.I. 1978. Effect of ${ }_{\mathrm{L}}$-glutamic acid and Siapton leaf organic fertilizer on oxidized nicotinamide adenine dinucleotide dependent glutamate dehydrogenase of different maize genotypes. Journal of Agricultural and Food Chemistry 26:12741276. doi:10.1021/jf60220a034.

Moreno-Hernández, J.M., Hernández-Mancillas, X.D., Coss-Navarrete, E.L., Mazorra-Manzano, M.A., Osuna-Ruiz, I., Rodríguez-Tirado, V.A., et al. 2017. Partial characterization of the proteolytic properties of an enzymatic extract from "aguama" Bromelia pinguin L. fruit grown in Mexico. Applied Biochemistry and Biotechnology 182:181-196. doi:10.1080/10408398.2017.1308312.

Muralidharan, N., Jeya-Shakila, R., Sukumar, D., and Jeyasekaran, G. 2013. Skin, bone and muscle collagen extraction from the trash fish, leather jacket (Odonus niger) and their characterization. Journal of Food Science and Technology 50:1106-1113. doi:10.1007/s13197-011-0440-y.

Naito, H., Ogawa, S., Valencia, M.O., Mohri, H., Urano, Y., Hosoi, F., et al. 2017. Estimating rice yield related traits and quantitative trait loci analysis under different nitrogen treatments using a simple tower-based field phenotyping system with modified single-lens reflex cameras. ISPRS Journal of Photogrammetry and Remote Sensing 125:50-62. doi:10.1016/j.isprsjprs.2017.01.010.

Oliveira, M.G., De Simone, S.G., Xavier, L.P., and Guedes, R.N. 2005. Partial purification and characterization of digestive trypsin-like proteases from the velvet bean caterpillar, Anticarsia gemmatalis. Comparative Biochemistry and Physiology Part B: Biochemistry and Molecular Biology 140:369-380. doi:10.1016/j.cbpc.2004.10.018.

Parrado, J., Bautista, J., Romero, E.J., García-Martínez, A.M., Friaza, V., and Tejada, M. 2008. Production of a carob enzymatic extract: Potential use as a biofertilizer. Bioresource Technology 99:2312-2318. doi:10.1016/j.biortech.2007.05.029.

Parrado, J., Escudero-Gilete, M.L., Friaza, V., García-Martínez, A., González-Miret, M.L., Bautista, J.D., et al. 2007. Enzymatic vegetable extract with bio- active components: Influence of fertiliser on the colour and anthocyanins of red grapes. Journal of the Science of Food and Agriculture 87:2310-2318. doi:10.1002/jsfa.2989.

Paul, K., Sorrentino, M., Lucini, L., Rouphael, Y., Cardarelli, M., Bonini, P., et al. 2019. Understanding the biostimulant action of vegetal-derived protein hydrolysates by high-throughput plant phenotyping and metabolomics: A case study on tomato. Frontiers in Plant Science 10:47. doi:10.3389/fpls.2019.00047.

Paul, T., Halder, S.K., Das, A., Bera, S., Maity, C., Mandal, A., et al. 2013. Exploitation of chicken feather waste as a plant growth promoting agent using keratinase producing novel isolate Paenibacillus woosongensis TKB2. Biocatalysis and Agricultural Biotechnology 2:50-57. doi:10.1016/j.bcab.2012.10.001. 
Pecha, J., Fürst, T., Kolomazník, K., Friebrová, V., and Svoboda, P. 2012. Protein biostimulant foliar uptake modeling: The impact of climatic conditions. AIChE Journal 58:2010-2019. doi:10.1002/aic.12739.

Pichereaux, C., Laurent, E.A., Gargaros, A., Viudes, S., Durieu, C., Lamaze, T., et al. 2019. Analysis of durum wheat proteome changes under marine and fungal biostimulant treatments using large-scale quantitative proteomics: A useful dataset of durum wheat proteins. Journal of Proteomics 200:28-39. doi:10.1016/j.jprot.2019.03.003.

Polo, J., Barroso, R., Ródenas, J., Azcón-Bieto, J., Cáceres, R., and Marfà, O. 2006. Porcine hemoglobin hydrolysate as a biostimulant for lettuce plants subjected to conditions of thermal stress. HortTechnology 16:483-487. doi:10.21273/HORTTECH.16.3.0483.

Qurartieri, M., Lucchi, A., and Cavani, L. 2002. Effects of the rate of protein hydrolysis and spray concentration on growth of potted kiwifruit (Actinidia deliciosa) plants. Acta Horticulturae 594:341-347. doi:10.17660/ActaHortic.2002.594.42.

Rajarajan, G., Irshad, A., Raghunath, B.V., Mahesh Kumar, G., and Punnagaiarasi, A. 2016. Utilization of cheese industry whey for biofuel-ethanol production. p. 59-64. In Prashanthi, M., and Sundaram, R. (eds.) Integrated waste management in India: status and future prospects for environmental sustainability. Springer, Cham, Switzerland.

Rouphael, Y., Colla, G., Giordano, M., El-Nakhel, C., Kyriacou, M.C., and De Pascale, S. 2017. Foliar applications of a legumederived protein hydrolysate elicit dose-dependent increases of growth, leaf mineral composition, yield and fruit quality in two greenhouse tomato cultivars. Scientia Horticulturae 226:353-360. doi:10.1016/j.scienta.2017.09.007.

Rouphael, Y., Spíchal, L., Panzarová, K., Casa, R., and Colla, G. 2018. High-throughput plant phenotyping for developing novel biostimulants: from lab to field or from field to lab? Frontiers in Plant Science 9:1197. doi:10.3389/fpls.2018.01197.

Schiavon, M., Ertani, A., and Nardi, S. 2008. Effects of an alfalfa protein hydrolysate on the gene expression and activity of enzymes of the tricarboxylic acid (TCA) cycle and nitrogen metabolism in Zea mays L. Journal of Agricultural and Food Chemistry 56:11800-11808. doi:10.1021/jf802362g.

Sestili, F., Rouphael, Y., Cardarelli, M., Pucci, A., Bonini, P., Canaguier, R., et al. 2018. Protein hydrolysate stimulates growth in tomato coupled with N-dependent gene expression involved in N assimilation. Frontiers in Plant Science 9:1233. doi:10.3389/fpls.2018.01233.

Sharma, S.S., and Dietz, K.J. 2006. The significance of amino acids and amino acid-derived molecules in plant responses and adaptation to heavy metal stress. Journal of Experimental Botany 57:711-726. doi:10.1093/jxb/erj073.

Soppelsa, S., Kelderer, M., Casera, C., Bassi, M., Robatscher, P., and Andreotti, C. 2018. Use of biostimulants for organic apple production: effects on tree growth, yield, and fruit quality at harvest and during storage. Frontiers in Plant Science 9:1342. doi:10.3389/fpls.2018.01342.

Spellman, D., McEvoy, E., O’Cuinn, G., and FitzGerald, R.J. 2003. Proteinase and exopeptidase hydrolysis of whey protein: Comparison of the TNBS, OPA and $\mathrm{pH}$ stat methods for quantification of degree of hydrolysis. International Dairy Journal 13:447-453. doi:10.1016/S0958-6946(03)00053-0.

Sun, J.Q., Jiang, H.L., and Li, C.Y. 2011. Systemin/jasmonate-mediated systemic defense signaling in tomato. Molecular Plant 4:607-615. doi:10.1093/mp/ssr008.

Sung, J., Ahn, S., Kim, N., Jeong, S.K., Kim, J., Chung, J., et al. 2010. Purification, molecular cloning, and biochemical characterization of subtilisin JB1 from a newly isolated Bacillus subtilis JB1. Applied Biochemistry and Biotechnology 162:900-911. doi:10.1007/s12010-009-8830-6.

Szabados, L., and Savouré, A. 2010. Proline: a multifunctional amino acid. Trends in Plant Science 15:89-97. doi:10.1016/j.tplants.2009.11.009.

Szerszunowicz, I., and Nalecz, D. 2018. The use of UniProtKB/BIOPEP for the analysis of oat globulin physicochemical parameters and bioactivity. Czech Journal of Food Sciences 36:119-125. doi:10.17221/455/2016-CJFS.

Takayama, S., and Sakagami, Y. 2002. Peptide signalling in plants. Current Opinion in Plant Biology 5:382-387. doi:10.1016/S1369-5266(02)00284-4.

Tavano, O.L. 2013. Protein hydrolysis using proteases: An important tool for food biotechnology. Journal of Molecular Catalysis B: Enzymatic 90:1-11. doi:10.1016/j.molcatb.2013.01.011.

Tejada, M., Rodríguez-Morgado, B., Paneque, P., and Parrado, J. 2018. Effects of foliar fertilization of a biostimulant obtained from chicken feathers on maize yield. European Journal of Agronomy 96:54-59. doi:10.1016/j.eja.2018.03.003.

Tsouvaltzis, P., Koukounaras, A., and Siomos, A.S. 2014. Application of amino acids improves lettuce crop uniformity and inhibits nitrate accumulation induced by the supplemental inorganic nitrogen fertilization. International Journal of Agriculture \& Biology 16:951-955. doi:13-300/2014/16-5-951-955.

Uniprot Consortium. 2015. UniProt: a hub for protein information. Nucleic Acid Research 43:204-212. doi:10.1093/nar/gku989.

Visconti, F., de Paz, J.M., Bonet, L., Jordà, M., Quiñones, A., and Intrigliolo, D.S. 2015. Effects of a commercial calcium protein hydrolysate on the salt tolerance of Diospyros kaki L. cv. "Rojo Brillante" grafted on Diospyros lotus L. Scientia Horticulturae 185:129-138. doi:10.1016/j.scienta.2015.01.028.

Wang, Y.H., and Irving, H.R. 2011. Developing a model of plant hormone interactions. Plant Signaling and Behavior 6:494500. doi:10.4161/psb.6.4.14558. 
Wilson, H.T., Amirkhani, M., and Taylor, A.G. 2018. Evaluation of gelatin as a biostimulant seed treatment to improve plant performance. Frontiers in Plant Science 9:1006. doi:10.3389/fpls.2018.01006.

Yamada, K., Yamaguchi, K., Shirakawa, T., Nakagami, H., Mine, A., Ishikawa, K., et al. 2016. The Arabidopsis CERK1-associated kinase PBL27 connects chitin perception to MAPK activation. The EMBO Journal 35:2468-2483. doi:10.15252/embj.201694248.

Yu, L.H., Wu, J., Zhang, Z.S., Miao, Z.Q., Zhao, P.X., Wang, Z., et al. 2017. Arabidopsis MADS-Box transcription factor AGL21 acts as environmental surveillance of seed germination by regulating ABI5 expression. Molecular Plant 10:834-845. doi:10.1016/j.molp.2017.04.004.

Zhang, H., Hu, Z., Lei, C., Zheng, C., Wang, J., Shao, S., et al. 2018. A plant phytosulfokine peptide initiates auxin-dependent immunity through cytosolic $\mathrm{Ca}^{2+}$ signaling in tomato. The Plant Cell 30:652-667. doi:10.1105/tpc.17.00537.

Zhao, L., Budge, S., Ghaly, A., Brooks, M., and Dave, D. 2011. Extraction, purification and characterization of fish pepsin: a critical review. Journal of Food Processing and Technology 2:1-14. doi:10.4172/2157-7110.1000126.

Zhou, Z., Zhao, Y., Bi, G., Liang, X., and Zhou, J.M. 2019. Early signalling mechanisms underlying receptor kinase-mediated immunity in plants. Philosophical Transactions of the Royal Society B 374:20180310. doi:10.1098/rstb.2018.0310. 